\title{
Outbreak of Acropora white syndrome following a mild bleaching event at Palmyra Atoll, Northern Line Islands, Central Pacific
}

Received: 15 February 2011/Accepted: 18 April 2011/Published online: 30 April 2011

(C) Springer-Verlag 2011
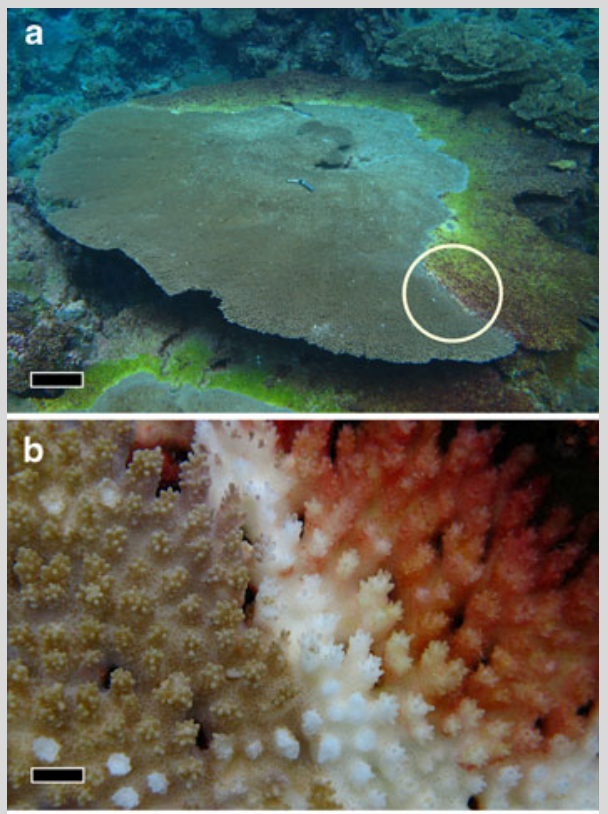

C

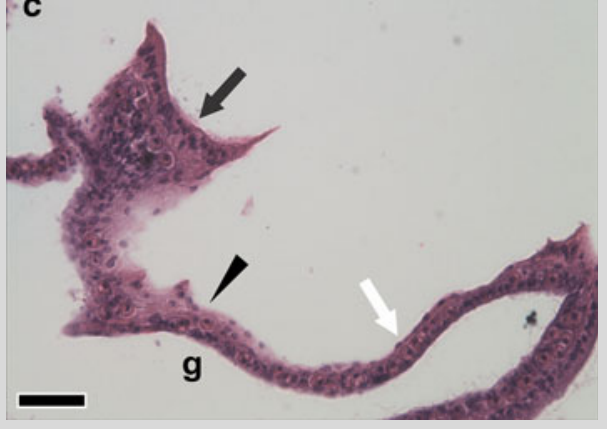

Fig. 1 Field signs of AWS affecting plating Acropora spp. at Palmyra Atoll. a Acropora cytherea with AWS;

bar $=15 \mathrm{~cm}$. b The progression from healthy tissue, to the active lesion zone, to coral skeleton colonized by a mixed algal turf assemblage; bar $=1 \mathrm{~cm}$. c Suspect wound repair in $A$. cytherea. Note exposed basal body wall with calicodermis (arrowhead), early squamous (white arrow), and later cuboidal to columnar (black arrow)

re-epithelialization; $\mathrm{g}=$ gastrovascular canal; bar $=20 \mu \mathrm{m}$
In October 2009, a mild bleaching event occurred at Palmyra Atoll $\left(05^{\circ} 52^{\prime} \mathrm{N} 162^{\circ} 05^{\prime}\right.$ W) in association with the strengthening of the 2009 El Niño-Southern Oscillation (Williams et al. 2010). Studies have shown coral disease outbreaks can follow thermal stress events on reefs (Bruno et al. 2007). Although bleaching prevalence within the genus Acropora was relatively low at Palmyra $(<10 \%)$, an outbreak of acute tissue loss disease was identified in February 2010 affecting plating Acropora on the shallow $(<5 \mathrm{~m})$ western reef terrace and northern backreef of the atoll (Fig. 1a, b). Field signs were consistent with Acropora white syndrome (AWS) reports from other parts of the Indo-Pacific (Aeby et al. 2011). This is the first report of such a disease at Palmyra since regular disease monitoring began in 2007. AWS prevalence within a permanent transect $\left(200 \mathrm{~m}^{2}\right)$ on the northern backreef equaled $0 \%$ (July 08, Oct 08, Jul 09, Oct 09), 6.3\% (Feb 10), and $22.9 \%$ (Jul 10) ( $n=35-48$ Acropora colonies across survey periods). On the western reef terrace, prevalence of AWS within 48 monitored A. cytherea colonies increased from $0 \%$ in Oct 2009 to $25 \%$ in July 2010, with four colonies experiencing over 50\% tissue loss. Histopathology of $A$. cytherea with AWS from Palmyra $(n=3)$ revealed dissociation of the gastrodermis with the liberation of zooxanthellae into the gastrovascular cavity and canals or wound repair (Fig. 1c). Although Palmyra's reefs are protected under US federal law and free from direct anthropogenic stressors, they are clearly not immune from the effects of global climate change and efforts are urgently needed to determine the etiology and dynamics of this destructive disease.

\section{References}

Aeby GS, Bourne DG, Wilson B, Work TM (2011) Coral diversity and the severity of disease outbreaks: A cross-regional comparison of Acropora White Syndrome in a species-rich region (American Samoa) with a species-poor region (Northwestern Hawaiian Islands). J Mar Biol Article ID 490198 doi:10.1155/2011/490198

Bruno JF, Selig ER, Casey KS, Page CA, Willis BL, Harvell CD, Sweatman H, Melendy AM (2007) Thermal stress and coral cover as drivers of coral disease outbreaks. PLoS Biol 5:1220-1227

Williams GJ, Knapp IS, Maragos JE, Davy SK (2010) Modeling patterns of coral bleaching at a remote Central Pacific atoll. Mar Pollut Bull 60:1467-1476

\section{G. J. Williams $(\bowtie)$}

Center for Marine Biodiversity and Conservation, Scripps Institution of Oceanography, La Jolla, CA 92083, USA

e-mail: gareth@ucsd.edu

\section{S. Knapp}

School of Biological Sciences and Centre for Marine Environmental and Economic Research, Victoria University of Wellington, PO Box 600,

Wellington, New Zealand

T. M. Work

US Geological Survey, National Wildlife Health Center, Honolulu Field Station, PO Box 50167, Honolulu, HI 96850, USA

E. J. Conklin

The Nature Conservancy, 923 Nuuanu Avenue, Honolulu, HI 96817, USA 